\begin{tabular}{|c|c|c|}
\hline & Int.J.Curr.Microbiol.App.Sci (2021) 10(09): $207-215$ & \\
\hline & $\begin{array}{l}\text { International Journal of Current Microbiology and Applied Sciences } \\
\text { ISSN: 2319-7706 Volume } 10 \text { Number } 09 \text { (2021) } \\
\text { Journal homepage: http://www.ijcmas.com }\end{array}$ & 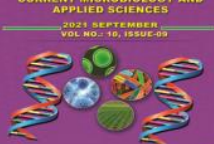 \\
\hline $\begin{array}{l}\text { EXCELLENT } \\
\text { PUBLISHERS }\end{array}$ & & \\
\hline
\end{tabular}

\title{
Isolation and Characterization of Brassicasterol from N-Hexane Fraction of Pometia pinnata and its Toxicity Test
}

\author{
Yoan De Nanda Herru, Adlis Santoni and Mai Efdi* \\ Department of Chemistry, Faculty of Mathematics and Natural Sciences, \\ Andalas University, Indonesia \\ *Corresponding author
}

\begin{tabular}{|c|c|}
\hline & A B S T R A C T \\
\hline Keywords & \multirow{4}{*}{$\begin{array}{l}\text { Pometia pinnata leaves were extracted and fractionated using n-hexane, } \\
\text { dichloromethane, ethyl acetate, and methanol. The four fractions obtained } \\
\text { were screened for cytotoxic testing using the Brine shrimp lethality test } \\
\text { (BSLT) method, n-hexane fraction has the highest } \mathrm{LC}_{50} 419,855 \mathrm{mg} / \mathrm{L} \text {. The } \\
\text { n-hexane fraction was continued for the isolation stage and a secondary } \\
\text { metabolite compound was obtained, namely brassicasterol. The structure of } \\
\text { this secondary metabolites was determined using spectroscopic methods } \\
\text { (UV-Vis, FTIR, and NMR). }\end{array}$} \\
\hline $\begin{array}{l}\text { Brassicasterol, brine } \\
\text { shrimp lethality test } \\
\text { (BSLT), } \\
\text { Pometia pinnata }\end{array}$ & \\
\hline Article Info & \\
\hline $\begin{array}{l}\text { Accepted: } \\
\text { 12 August } 2021 \\
\text { Available Online: } \\
\text { 10 September } 2021\end{array}$ & \\
\hline
\end{tabular}

\section{Introduction}

Matoa or Kasai (Pometia pinnata) is a tropical plant belonging to the Sapindaceae family that has spread throughout the tropics, especially in Indonesia (Martiningsih et al., 2016). In traditional plants used by the community as a remedy injury (Lely, 2016), fever, and fatigue, as well as anti-infection of wounds (Garuda and Syafruddin, 2014) and also there are used as dye batik cloth (Haerudin and Farida, 2017). This plant has been carried out various kinds of bioactivity tests. Some of which have been reported by the researchers before, like antioxidant (Martiningsih et al., 2016), antimicrobial (Lely, 2016), the treatment of anti-
HIV-1 (Suedee et al., 2013) antihyperglycemic (Paris Mataputun et al., 2013) (Paris Mataputun et al., 2013) and cytotoxic (Trimedona et al., 2018). For the cytotoxic test, the air is based on research conducted by (Trimedona et al., 2018) in the know that the fraction with $\mathrm{n}$ use-values LC 50 relative contained in the n-hexane fraction Pometia pinnata with $\mathrm{LC}_{50} 33.0958 \pm 4.5722 \mathrm{mg} / \mathrm{mL}$.

This plant's secondary metabolites have been isolated by (Mohammad, Noorwala, Ahmad, Zahoor, \& Lajis, (2012)was new triterpenoid saponin group, namely pometin, kaemferol 3O- $\alpha$-L-rhamnopyranosid, and 3-O- $[\alpha-\mathrm{L}-$ 
arabinofuranosil- $(1 \rightarrow 4)$ - $\alpha$-L-rhamnopyranosyl- $(1 \rightarrow 2)$ - $\alpha$ - L -arabinopyranosyl] hederagenin isolated with methanol extract on the leaves and bark of Pometia pinnata. The leaves were isolated secondary metabolites which belong to the other triterpenoid saponins in the form of 3-O- [ $\alpha$-L-arabinofuranosyl- (1-4) - $\alpha$-L-rhamno-pyranosyl- (12) - $\alpha$-L-arabinopyranosyl] - hederagenin. (Mohammad et al., 2012) and the flavonoid group in the form of epicatechin, kaempferol3-O-rhamnoside, quercetin-3-O-rhamnoside, and proanthocyanidin A. Other secondary metabolite compounds reported in the leaves are the glycolipid group in the form of 1-Opalmitoyl-3-O- [ $\alpha$-D-galacto-pyranosyl- $(1 \rightarrow$ 6) - $\beta$-D-galactopyranosyl] -sn-glycerol, a steroid glycoside group in the form of stigmasterol-3-O-glucoside and a pentacyclic triterpenoid group, namely $3-\mathrm{O}-\alpha-\mathrm{L}$ arabinofuranosyl $(1 \rightarrow 3)$ - [ $\alpha$-L-rhamno-pyranosyl (1 $\rightarrow 2)$ ] - $\alpha$-L-arabinopyranosyl - hederagenin (Suedee et al., 2013). Based on the research report above, it is known that isolation is still rarely carried out using the n-hexane Pometia pinnata fraction.

\section{Materials and Methods}

\section{Chemical and reagents}

The materials used include dry Pometia pinnata leaves, organic solvents such as nhexane, dichloromethane, chloroform, ethyl acetate and methanol, distilled water, aluminum foil, cotton, silica gel 60 (0.0630,200 $\mathrm{mm} \mathrm{/} \mathrm{Merck),} \mathrm{and} \mathrm{chromatography}$ plate. Merck's DC-Alufolien Kieselgel 60 F254 thin layer $(20 \times 20 \mathrm{~cm})$. The reagents used to test the content of secondary metabolites are Iron (III) Chloride, Mercury (II) Chloride, Potassium Iodide, Concentrated Sulfuric Acid, Acetic Anhydride, Sodium Hydroxide, Magnesium Powder, and Ammonia. The appearance of stains on thin-layer chromatography was used $10 \% \mathrm{H}_{2} \mathrm{SO}_{4}$ and Liebermann-Buchard reagent. Materials for the cytotoxic activity test are shrimp larvae, seawater, Dimethyl Sulfoxide (DMSO).

\section{Extraction and Fractionation}

Pometia pinnata leaves sample were obtained from the Andalas University Campus area, Limau Manis, Padang. Pometia pinnata leaves (13 kg) were cleaned and air dried, then mashed using a grinder and obtained $6 \mathrm{~kg}$ of dry sample. $6 \mathrm{~kg}$ of dry powder of Pometia pinnata leaves was macerated using $5 \mathrm{~L}$ of methanol as a solvent with 6 repetitions. The extract obtained was then concentrated using a rotary evaporator to obtain a concentrated extract of $180 \mathrm{~g}$ of methanol. The concentrated methanol extract was fractionated successively using n-hexane, dichloromethane, and ethyl acetate.

\section{Phytochemical Screening}

Secondary metabolites in Pometia pinnata as terpenoid, steroid, phenols, alkaloid and coumarin were investigated with the standard method described by Lantah, Montolalu, \& Reo (2017) and (Alegantina and Isnawati, 2010)

\section{Activity Test of Cytotoxic from Pometia pinnata fraction using Brine Shrimp Lethality Test (BSLT) Method}

Screening of cytotoxic activity from fraction was carried out according to the method described by (Musa, 2012) and (Al-Saeedi, Al-Ghafri, \& Hossain, 2017). For LC 50 determination was calculated using the following formula by(Gelani and Uy, 2016)

\section{Isolation and Purification}

The n-hexane fraction (30 grams) was separated using a chromatography column with a silica gel stationary phase (0.063-0.200 mesh) and the mobile phase in the form of $n$ hexane: ethyl acetate (10: 0 - 0:10) and ethyl 
acetate: methanol $(10: 0$ - 9,5: 0,5). Eluate is stored in the vial, then grouped according to the separation pattern, and obtained 17 subfractions (A-Q). Subfraction is remonitored the separation pattern by the thinlayer chromatography method. fraction $G$ is selected to proceed to the purification stage. The impurity fraction $G$ was dissolved using n-hexane and ethyl acetate until a white, needle-shaped crystal formed. This white solid was continued for purity test using the thinlayer chromatography method and melting point test.

\section{Results and Discussion}

\section{Phytochemical Screening}

Pometia pinnata's extract was tested by phytochemical to determine the class of compounds present in the extract by testing the alkaloids, flavonoids, phenolics, terpenoids-steroids, coumarin, and saponins. Based on the results of the phytochemical test, the positive extract contained flavonoids, phenolics, and terpenoids-steroids. This is following the research that has been done (Trimedona et al., 2015), that the Pometia pinnata plant extract contains triterpenoids, steroids, flavonoids, and phenolics. Other studies have also reported the results of phytochemical screening from the n-hexane extract of Pometia pinnata leaves containing alkaloid, flavonoid, terpenoid and tannin class compounds (Kuspradini et al., 2016). The hypothesis is that the dominant compound in Pometia pinnata leaves is in the form of phytosterols because of the results of research from other researchers which states that phytosterols are the most dominant compounds in seed plant isolation including open seeds and closed seeds (Tonius et al., 2016).

\section{Cytotoxic Screening}

Brine Shrimp Lethality Test used in this research to determine which fraction has the highest $\mathrm{LC}_{50}$. Determine $\mathrm{LC}_{50}$ use the regression equation, it can be seen below:

\section{Regression equation}

$Y=a+b X$

\section{Information}

Y: Probit value, percentage of deaths

$\mathrm{X}$ : Logarithm of concentration of test material

a: Constants

b: Slope / slope (Gelani \& Uy, 2016)

Based on the test results shows that the nhexane fraction has strong toxicity properties compared to dichloromethane, ethylacetate, and methanol fractions. With the $\mathrm{LC}_{50}$ values in sequence, namely n-hexane of 419,855mg / $\mathrm{L}$, dichloromethane of $647.99 \mathrm{mg} / \mathrm{L}$, ethyl acetate of $671.06 \mathrm{mg} / \mathrm{L}$ and methanol of $727.78 \mathrm{mg}$.

This is following previous research conducted by Trimedona et al., 2018 in a cytotoxic test on the bark of Pometia pinnata that n-hexane extract is more toxic than ethyl acetate, acetone, and methanol extracts.

The toxicity possessed by the n-hexane fraction in the leaves of Pometia pinnata is classified as moderately toxic. A compound is known to be highly toxic if the $\mathrm{LC}_{50}$ value of lettuce is in the range $0-100 \mu \mathrm{g} / \mathrm{mL}$, moderate toxicity is at $100-500 \mu \mathrm{g} / \mathrm{mL}$, low toxicity is at $500-1000 \mu \mathrm{g} / \mathrm{mL}$ and is not toxic above $1000 \mu \mathrm{g} / \mathrm{mL}$ (Gelani \& Uy, 2016). N-hexane fraction selected for isolation and purification step.

\section{Isolation of Secondary Metabolites}

The compounds isolated in this research are 
sterol group compounds. This has been proved with a purity test using the thin layer chromatography method with the help of spot visors in the form of Liebermann-Buchard reagent and $10 \% \mathrm{H}_{2} \mathrm{SO}_{4}$. Testing with thin layer chromatography method produces a single red-purple stain on the thin layer chromatography plate which indicates that the isolated compound is a sterol group compound (Gerlach et al., 2018). The second method to determine if the isolated compound is pure is to use the melting point test method. The results of the melting point test show that the isolated compound has a melting point range of $154-155^{\circ} \mathrm{C}$. This shows that the isolated compound has been pure where the melting point range of a pure compound is $1{ }^{\circ} \mathrm{C}$.

From these two purity test data, there are secondary metabolites of the sterol group which is similar to the data above. The compound that have been isolated are predicted as a brassicasterol compound. This analysis is also strengthened by UV, IR, and NMR spectroscopic analysis.

\section{Spectroscopic Analysis}

This isolated compound had maximum absorption at a wavelength of $245 \mathrm{~nm}$ from UV spectrum analysis. The absorption value indicates the presence of a double bond between the carbons $(\mathrm{C}=\mathrm{C})$, but this double bond does not conjugate. This happens because of the electron transition from $\pi$ to $\pi$ *. This is also confirmed by the thin-layer chromatography test, where the chromatography plate that has been spotted with eluent with UV light at a wavelength of $356 \mathrm{~nm}$ does not glow. So this proves that pure compounds have $\mathrm{C}=\mathrm{C}$ bonds that are not conjugated (Abubakar et al., 2017). IR spectroscopic measurements were carried out to determine the functional group structure of the isolated steroid group compounds. There is absorption at wave number $3416.67 \mathrm{~cm}^{-1}$ which indicates that there is a hydroxyl group $(-\mathrm{OH})$ which is indicated by the presence of strain between oxygen and hydrogen. This is also evidenced in the fingerprint area, namely the absorption at the wave number 1023.38 $\mathrm{cm}^{-1}$, which indicates that there are $\mathrm{C}-\mathrm{O}$ groups experiencing vibrations. The absorption at wavenumbers $2933.04 \mathrm{~cm}^{-1}$ and $2862.40 \mathrm{~cm}^{-1}$ indicates the presence of primary $\mathrm{C}-\mathrm{H}$ groups and also secondary $\mathrm{C}-\mathrm{H}$ groups which are aliphatic. This is evidenced by the absorption at wave number $1456.88 \mathrm{~cm}^{-}$ 1 which is the fingerprint area for the $\mathrm{C}-\mathrm{H}$ group of alkanes.

The absorption at wavenumber $1639.59 \mathrm{~cm}^{-1}$ indicates that the isolated steroid compound has a non-conjugated $\mathrm{C}=\mathrm{C}$ double bond. This is evidenced by the absence of wave number absorption in the $1500 \mathrm{~cm}^{-1}$ fingerprint area.

Based on the results of the spectrum analysis obtained, it is known that the secondary metabolite compounds resulting from isolation are steroid class compounds, in the presence of the $\mathrm{OH}$ group and the unconjugated $\mathrm{C}=\mathrm{C}$ double bond group which is the characteristics of steroid compounds.

Nuclear magnetic resonance spectroscopy or NMR spectroscopy was used in this study, namely, ${ }^{1} \mathrm{H}-\mathrm{NMR}$ and ${ }^{13} \mathrm{C}-\mathrm{NMR}$. Chemical shift data of ${ }^{1} \mathrm{H}-\mathrm{NMR}$ and ${ }^{13} \mathrm{C}-\mathrm{NMR}$ isolated steroid compound were compared with chemical shift data from the literature (Jinming et al., 2001). 
Table.1 1H-NMR data (500 MHz, CDCl3) and 13C-NMR (125 MHz, $\mathrm{CDCl}_{3}$ ) of isolated compound and comparative literature data from Brassicasterol (Jinming et al., 2001)

\begin{tabular}{|c|c|c|c|c|c|c|}
\hline \multirow[t]{2}{*}{ S.No } & \multicolumn{4}{|c|}{ Secondary Metabolite } & \multicolumn{2}{|c|}{ Brassicasterol } \\
\hline & $\Delta \mathrm{c}(\mathrm{ppm})$ & DEPT & HSQC & HMBC & $\Delta c(p p m)$ & $\delta_{\mathrm{H}}(\mathrm{ppm})$ \\
\hline 1 & 37,3844 & $\mathrm{CH}_{2}$ & $1,8524(\mathrm{H} 1)$ & $71,9498(\mathrm{C} 3)$ & 37,54 & \\
\hline 2 & 29,0823 & $\mathrm{CH}_{2}$ & $\begin{array}{l}1,2485(\mathrm{H} 2) \\
1,7015(\mathrm{H} 2)\end{array}$ & & 31,95 & \\
\hline 3 & 71,9498 & $\mathrm{CH}-\mathrm{OH}$ & $3.5219(\mathrm{H} 3)$ & & 72,04 & 3,53 \\
\hline 4 & 42,3455 & $\mathrm{CH}_{2}$ & $2,274(\mathrm{H} 4)$ & $\begin{array}{c}71,9498 \text { (C3) } \\
140,8764 \text { (C5) } \\
121,8667 \text { (C6) } \\
31,7851 \text { (C7) } \\
36,6485 \text { (C10) }\end{array}$ & 42,58 & \\
\hline 5 & 140,8764 & $\mathrm{C}$ & - & & 141 & - \\
\hline 6 & 121,8667 & $\mathrm{CH}$ & $5.3496(\mathrm{H} 6)$ & $\begin{array}{c}42,3455(\mathrm{C} 4) \\
31,7851(\mathrm{C} 7) \\
36,6485(\mathrm{C} 10)\end{array}$ & 121,9 & \\
\hline 7 & 31,7851 & $\mathrm{CH}_{2}$ & $\begin{array}{l}1,8160(\mathrm{H} 7) \\
1,9752(\mathrm{H} 7)\end{array}$ & & 32,16 & \\
\hline 8 & 32,0291 & $\mathrm{CH}$ & $1,4492(\mathrm{H} 8)$ & $21,23(\mathrm{C} 11)$ & 33,34 & \\
\hline 9 & 51,3804 & $\mathrm{CH}$ & $1,5253(\mathrm{H} 9)$ & $32,029(\mathrm{C} 8)$ & 50,51 & \\
\hline 10 & 36,6485 & $\mathrm{C}$ & - & & 36,78 & \\
\hline 11 & 21,3633 & $\mathrm{CH}_{2}$ & 1,4909(H11) & $56,9978(\mathrm{C} 14)$ & 21,32 & \\
\hline 12 & 39,8087 & $\mathrm{CH}_{2}$ & $1,9752(\mathrm{H} 12)$ & & 39,96 & \\
\hline 13 & 42,4267 & $\mathrm{C}$ & - & & 42,58 & - \\
\hline 14 & 56,9978 & $\mathrm{CH}$ & $1,1556(\mathrm{H} 14)$ & $12,1883(\mathrm{C} 18)$ & 57,12 & \\
\hline 15 & 24,5071 & $\mathrm{CH}_{2}$ & $1,5447(\mathrm{H} 15)$ & $32,0291(\mathrm{C} 8)$ & 24,51 & \\
\hline 16 & 25,5654 & $\mathrm{CH}_{2}$ & $\begin{array}{l}1,4503 \text { (H16) } \\
1,1713 \text { (H16) }\end{array}$ & $\begin{array}{c}32,0291 \text { (C8) } \\
42,4267 \text { (C13) } \\
12,1883 \text { (C18) }\end{array}$ & 28,68 & \\
\hline 17 & 56,0669 & $\mathrm{CH}$ & $1,1516(\mathrm{H} 17)$ & $\begin{array}{l}12,1883(\mathrm{C} 18) \\
21,3633(\mathrm{C} 11)\end{array}$ & 56,36 & \\
\hline 18 & 12,1883 & $\mathrm{CH}_{3}$ & $0.6940(\mathrm{H} 18)$ & $\begin{array}{l}39,8087 \text { (C12) } \\
42,4267 \text { (C13) }\end{array}$ & 12,3 & 0,69 \\
\hline 19 & 21,2069 & $\mathrm{CH}_{3}$ & 0,8362 (H19) & 51,3804 (C9) & 20,12 & 0,83 \\
\hline 20 & 40,6686 & $\mathrm{CH}$ & $2,0264(\mathrm{H} 20)$ & & 40,26 & \\
\hline 21 & 21,2531 & $\mathrm{CH}_{3}$ & $1,0244(\mathrm{H} 21)$ & $\begin{array}{c}40,6686(\mathrm{C} 20) \\
138,4801(\mathrm{C} 23) \\
24,5071(\mathrm{C} 15)\end{array}$ & 21,28 & 1 \\
\hline 22 & 129,3881 & $\mathrm{CH}$ & $5.0171(\mathrm{H} 22)$ & $\begin{array}{c}40,6686(\mathrm{C} 20) \\
138,4801(\mathrm{C} 23) \\
50,2728(\mathrm{C} 24\end{array}$ & 136,1 & 5,2 \\
\hline 23 & 138,4801 & $\mathrm{CH}$ & $5.1396(\mathrm{H} 23)$ & $\begin{array}{c}40,6686(\mathrm{C} 20) \\
129,3881(\mathrm{C} 22) \\
50,2728(\mathrm{C} 24)\end{array}$ & 132 & 5,17 \\
\hline 24 & 50,2728 & $\mathrm{CH}$ & $0,9362(\mathrm{H} 24)$ & & 43,06 & \\
\hline 25 & 32,0291 & $\mathrm{CH}_{3}$ & $1,5253(\mathrm{H} 25)$ & $50,13(\mathrm{C} 24)$ & 33,34 & \\
\hline 26 & 19,5492 & $\mathrm{CH}$ & 1,0075 (H26) & $50,2728(\mathrm{C} 24)$ & 19,84 & \\
\hline 27 & 19,1205 & $\mathrm{CH}_{3}$ & $0,7855(\mathrm{H} 27)$ & & 19,58 & \\
\hline 28 & 12,4127 & $\mathrm{CH}_{3}$ & 0.7944 (H28) & $32,0291(\mathrm{C} 25)$ & 17,8 & \\
\hline
\end{tabular}


Fig.1 Brine Shrimp Lethality Test result

N - Hexane Fraction

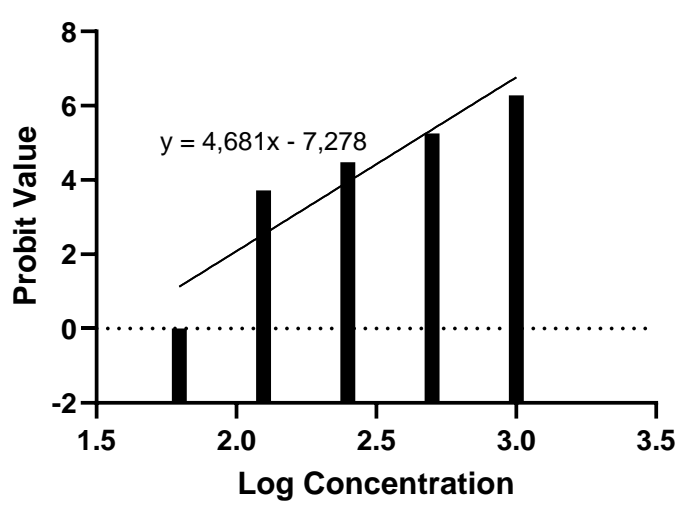

Ethyl Acetate Fraction

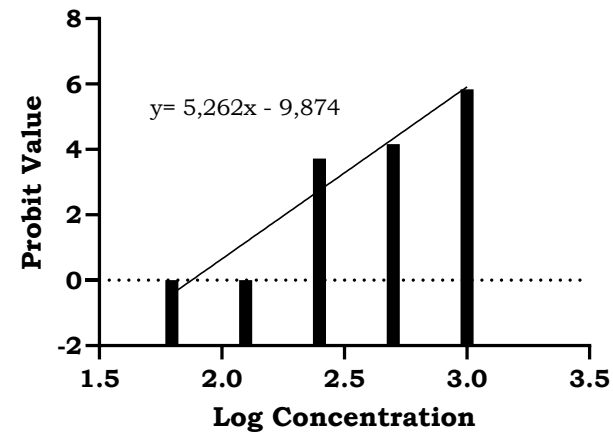

Dichloromethane Fraction

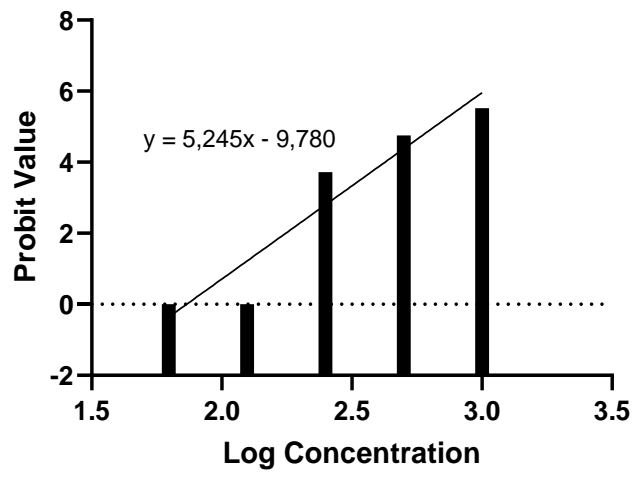

Methanol Fraction

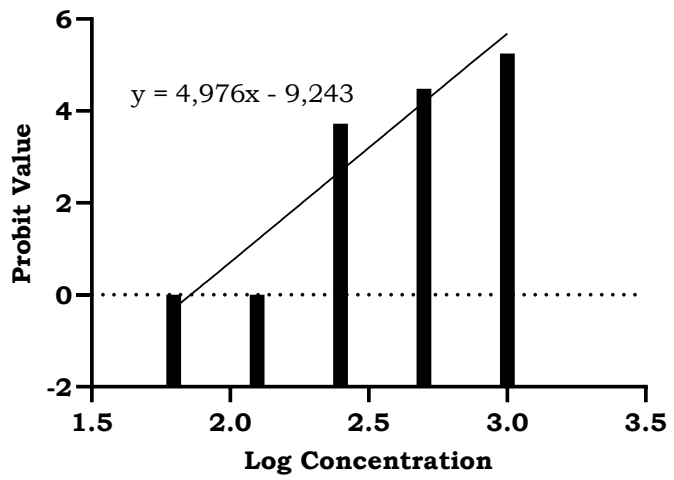

Fig.2 The HSQC correlation spectrum for the isolated compound

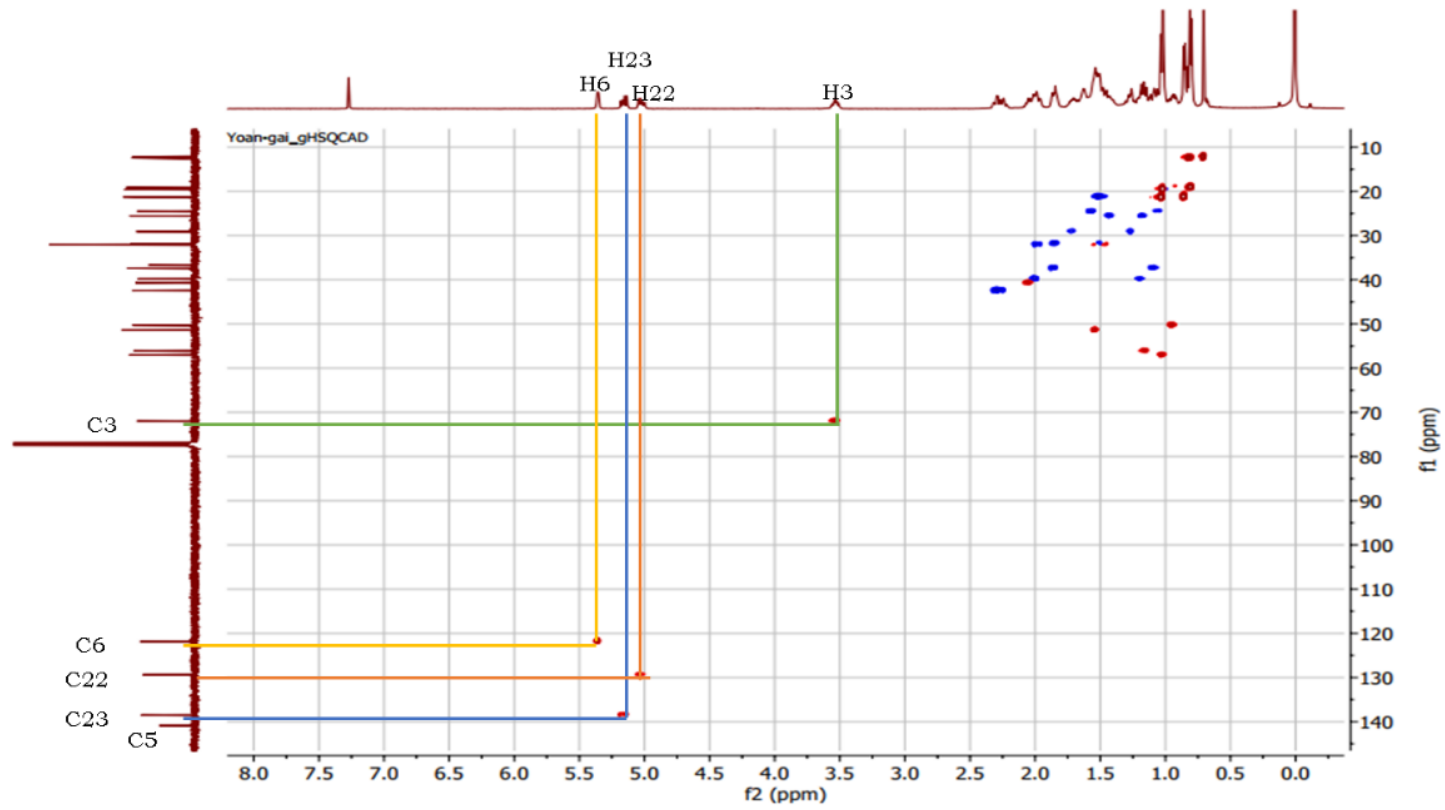


Fig.3 Correlation spectrum of HMBC for Isolated Compound

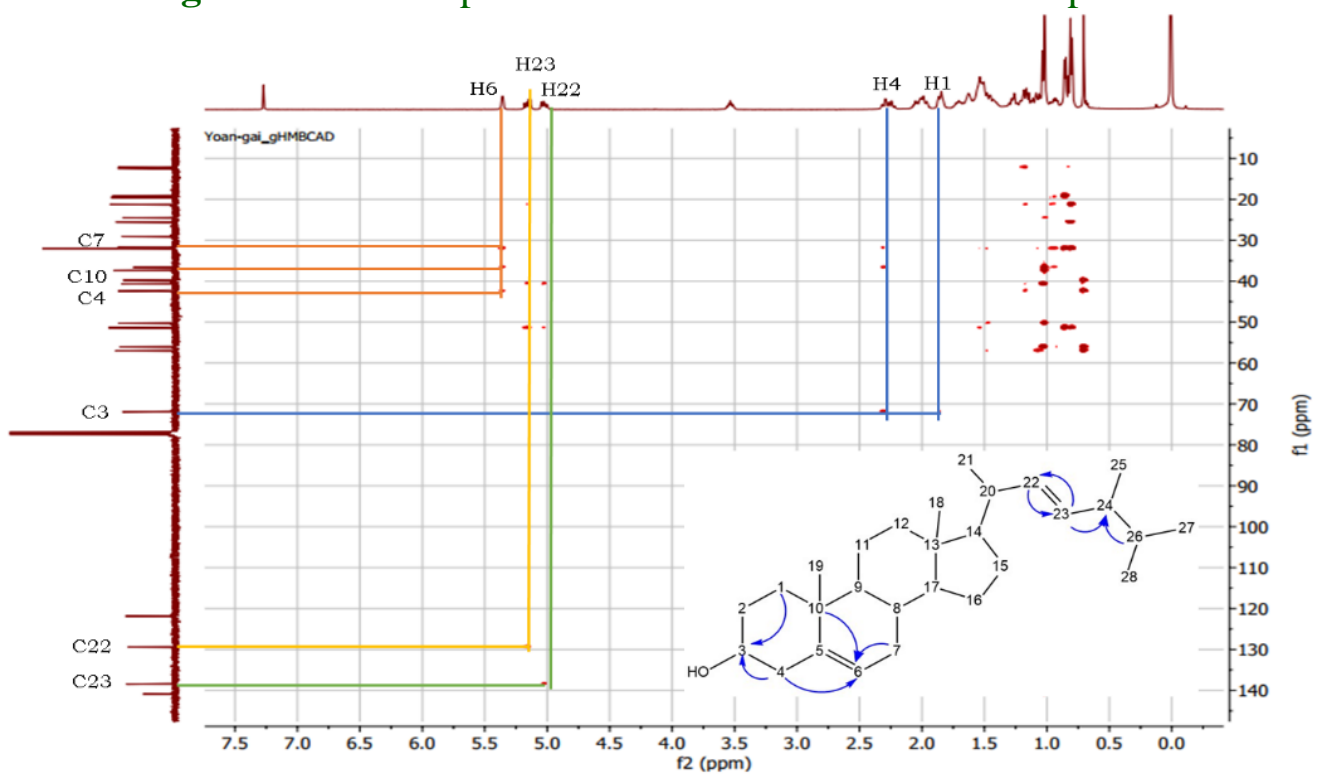

Fig.4 HMBC Correlation

Fig.5 Structure of Brassicasterol ((22E, 24R) Ergosta-5, 22-dien-3b-ol)

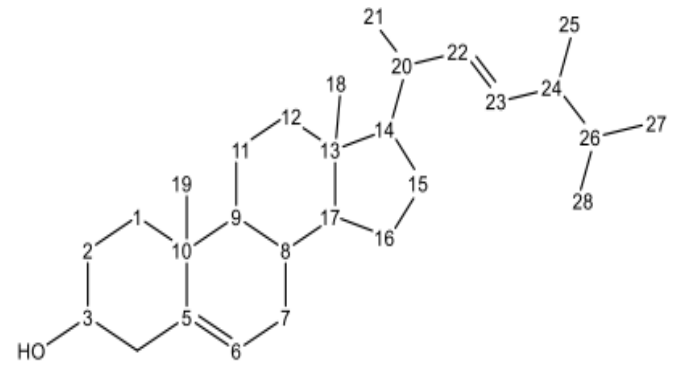

Based on comparative literature data, it is known that the predicted isolated steroid compounds are brassicasterol compounds. Brassicasterol is a sterol compound (Figure 5). ${ }^{1} \mathrm{H}-\mathrm{NMR}$ and ${ }^{13} \mathrm{C}-\mathrm{NMR}$ chemical shift data obtained from this study with comparisons can be seen in Table 1 . Analysis of the ${ }^{13} \mathrm{C}$-NMR spectrum $\left(125 \mathrm{MHz}, \mathrm{CDCl}_{3}\right.$ ) shows that the isolated steroid compound has 28 carbons. From the DEPT-135 analysis with the help of the HSQC analysis, it is known that there are six methyl carbons, eight methylene carbons, eleven methine carbons, and three quaternary carbons.
Analysis based on literature obtained ${ }^{1} \mathrm{CNMR}$, DEPT, and HSQC data, it is known that there is one signal $\mathrm{C}$ atom which is estimated to overlap with each other. This overlap signal is estimated between C-8 and C-25. This is because the chemical environment of the two is almost the same. In addition to the known overlap in C-8 and C-25, it is known that there is one hydroxy group from pure isolate that appears in the chemical shift of $71.9498 \mathrm{ppm}$. It is also known that two double bonds give rise to a carbon signal in the chemical shift of 121.8667 ppm, 129.3881 ppm, 138.4801 ppm, and 140.8764 ppm (Figure 4.). 
The HMBC data above strengthens the positioning of each carbon that has been known to be correlated from the HSQC data that has been analyzed previously. In Figure 5, it can be seen that $\mathrm{C} 3$, which is the carbon that binds the hydroxyl group, is correlated with H1. Figure 5 depicts H6 which is a proton for one of the vinyl groups correlating with $\mathrm{C} 4$, $\mathrm{C} 7$, and $\mathrm{C} 10 . \mathrm{C} 23$ carbon which is the carbon for the vinyl group has a correlation with $\mathrm{H} 23$ and the proton $\mathrm{H} 22$ which is one of the protons that binds to the carbon making up the vinyl group correlates with $\mathrm{C} 20, \mathrm{C} 23$, and C24. Figure 5 shows a correlation between $\mathrm{H} 4$ and $\mathrm{C} 5$ and C6. There is also a correlation between $\mathrm{H} 22$ and $\mathrm{C} 23, \mathrm{H} 23$ and $\mathrm{C} 22$.

The data above can also be simulated the correlation of HMBC in Figure 6. The chemical shift analysis of the data for the isolated steroid compounds is quite similar to the comparative data. The structure of the brassicasterol compound can be seen in Figure 7. The brassicasterol compound has a similar structure to the isolated stigmasterol compound (Rohmawati \& Sutoyo, 2018) from Pometia pinnata. Structurally, these two compounds are similar, namely the location of the vinyl groups at positions $\mathrm{C} 5, \mathrm{C} 6, \mathrm{C} 22$, and $\mathrm{C} 23$. The location of the $-\mathrm{OH}$ group of these two compounds also has similarities where both are at $\mathrm{C} 3$. The thing that distinguishes these two compounds is the amount of carbon. Brassicasterol has a total carbon of 28 while the stigmasterol compound has a carbon of 29 where the carbon is located at C26. The compound isolated from the leaves of Pometia pinnata is thought to be a steroid class compound, namely brassicasterol. This is supported by the carbon and proton analysis of NMR, DEPT, HSQC, and HMBC showing a spectrum consistent with the literature. The cytotoxic test results on the n-hexane, dichloromethane, ethylacetate, and methanol fractions showed that the n-hexane fraction was more active with a value of LC50419.855 mg / L. However, the cytotoxic properties of the brassicasterol compound that have been isolated have not been carried out due to the small number of samples. It is hoped that later tests will be carried out for the cytotoxic properties of this isolated brassicasterol compound.

\section{References}

Abubakar, A. N. F., Achmadi, S. S., \& Suparto, I. H. (2017). Triterpenoid of avocado (Persea americana) seed and its cytotoxic activity toward breast MCF-7 and liver HepG2 cancer cells. Asian Pacific Journal of Tropical Biomedicine, 7(5), 397-400.

Al-Saeedi, A. H., Al-Ghafri, M. T. H., \& Hossain, M. A. (2017). Brine shrimp toxicity of various polarities leaves and fruits crude fractions of Ziziphus jujuba native to Oman and their antimicrobial potency. Sustainable Chemistry and Pharmacy, 5(January), 122-126.

Alegantina, S., \& Isnawati, A. (2010). Identifikasi dan penetapan kadar senyawa kumarin dalam ekstrak metanol. Buletin Penelitian Kesehatan, Vol. 38, pp. 17-28.

Gelani, C. D., \& Uy, M. M. (2016). Cytotoxicity to Artemia salina L. of marine sponge extracts from Surigao del Norte, Philippines. Bulletin of Environment, Pharmacology and Life Sciences, 5(April), 14-18.

Jinming, G., Lin, H., \& Jikai, L. (2001). A novel sterol from Chinese truffles Tuber indicum. Steroids, 66(10), 771775.

Kuspradini, H., Pasedan, W. F., \& Kusuma, I. W. (2016). Aktivitas Antioksidan dan Antibakteri Ekstrak Daun Pometia pinnata. 1, 26-34.

Lantah, P. L., Montolalu, L. A., \& Reo, A. R. (2017). Kandungan Fitokimia dan 
Aktivitas Antioksidan Ekstrak Metanol Rumput Laut Kappaphycus alvarezii. Media Teknologi Hasil Perikanan, 5(3), 73.

Mohammad, F. V., Noorwala, M., Ahmad, V. U., Zahoor, A., \& Lajis, N. H. J. (2012). A new monodesmosidic triterpenoid saponin from the leaves of Pometia pinnata. Natural Product Communications, 7(11), 1423-1426.

Musa, A. A. (2012). Cytotoxicity activity and phytochemical screening of Cochlospermum tinctorium perr ex A. Rich rhizome. Journal of Applied
Pharmaceutical Science, 2(7), 155159.

Tonius, J., Wibowo, M. A., \& Idiawati, N. (2016). Isolasi dan Karakterisasi Senyawa Steroid Fraksi N -Heksana Daun Buas-Buas (Premna serratifolia L.). 5(1), $1-7$.

Trimedona, N., Nurdin, H., Darwis, D., \& Efdi, M. (2015). Isolation of triterpenoid from stem bark of Pometia pinnata, forst \& forst. Journal of Chemical and Pharmaceutical Research, 7(11), 225-227.

\section{How to cite this article:}

Yoan De Nanda Herru, Adlis Santoni and Mai Efdi. 2021. Isolation and Characterization of Brassicasterol from N-Hexane Fraction of Pometia pinnata and its Toxicity Test. Int.J.Curr.Microbiol.App.Sci. 10(09): 207-215. doi: https://doi.org/10.20546/ijcmas.2021.1009.024 